\title{
Preparation of Reduced Pt-Based Catalysts with High Dispersion and Their Catalytic Performances for NO Oxidation
}

\author{
Xinmei Ding ${ }^{1}$, Yanli Liang ${ }^{2}$, Hailong Zhang ${ }^{3}$, Ming Zhao ${ }^{1, *}$, Jianli Wang ${ }^{1, *}$, Yaoqiang Chen ${ }^{1}$ \\ ${ }^{1}$ Key Laboratory of Green Chemistry \& Technology of the Ministry of Education, College of Chemistry, Sichuan University, \\ Chengdu 610064, China. \\ ${ }^{2}$ State Key Laboratory of Polymer Materials Engineering of China (Sichuan University), Polymer Research Institute of Sichuan \\ University, Chengdu 610064, China. \\ ${ }^{3}$ Department of Chemistry, College of Chemistry and Chemical Engineering, Xiamen University, Xiamen 361005, \\ Fujian Province, China.
}

\begin{abstract}
Pt-based catalysts are widely used in diesel oxidation catalyst (DOC) units, primarily to oxidize the harmful $\mathrm{HC}, \mathrm{CO}$, and $\mathrm{NO}$ emissions. Notably, $\mathrm{NO}_{2}$ produced from NO oxidation is beneficial for lowtemperature activity in $\mathrm{NH}_{3}-\mathrm{SCR}$ and promotes soot oxidation in diesel particulate filters (DPF). Thus, the conversion of $\mathrm{NO}$ is an important parameter for determining the performance of DOCs. Considering the increasingly stringent emission regulations and the

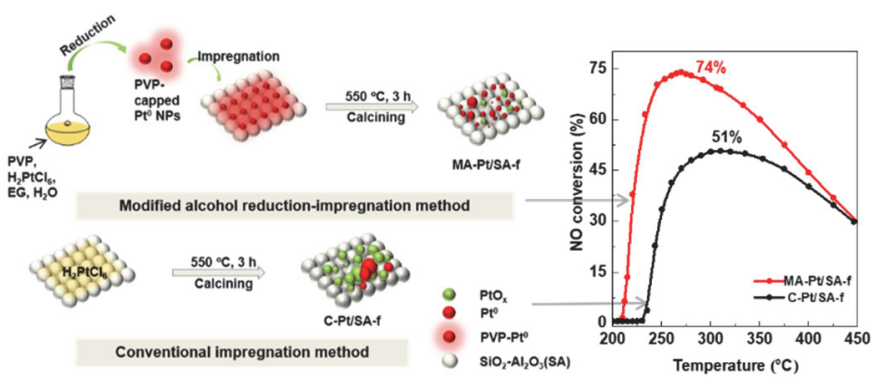
economic effectiveness, preparation of low-cost and highly active Pt-based catalysts is indispensable. Generally, the $\mathrm{Pt}^{0}$ content is crucial as it is an active component of DOCs. Small Pt size is beneficial for improving the catalytic activity. In this study, we applied a modified alcohol reduction-impregnation (MARI) method to synthesize highly active 1\% ( $w$, mass fraction) $\mathrm{Pt} / \mathrm{SiO}_{2}-\mathrm{Al}_{2} \mathrm{O}_{3}$ (denoted as $\mathrm{MA}-\mathrm{Pt} / \mathrm{SA}$ ) catalyst. Meanwhile, using the conventional impregnation method, we prepared the $\mathrm{Pt} / \mathrm{SiO}_{2}-\mathrm{Al}_{2} \mathrm{O}_{3}$ catalyst with the same $\mathrm{Pt}$ loading (denoted as $\mathrm{C}-\mathrm{Pt} / \mathrm{SA}$ ) as a reference sample. $\mathrm{X}$-ray photoelectron spectroscopy (XPS) and hydrogen temperature program reduction ( $\mathrm{H}_{2}$-TPR) analyses proved that the MARI method could produce $\mathrm{Pt}$ catalysts with higher $\mathrm{Pt}^{0}$ content. $\mathrm{Pt}^{0}$ content in MA-Pt/SA was $\sim 60.3 \%$ while that in $\mathrm{C}$ - $\mathrm{Pt} / \mathrm{SA}$ was only $\sim 23.1 \%$. X-ray diffraction (XRD), CO-diffuse reflectance infrared Fourier transform spectroscopy (CO-DRIFTS), and transmission electron microscopy (TEM) characterization confirmed that the Pt particle size is much smaller over MA-Pt/SA as compared to that over C-Pt/SA. Performance evaluation of MA-Pt/SA and C-Pt/SA was conducted in a simulated diesel atmosphere. The results showed that the maximum $\mathrm{NO}$ conversion into $\mathrm{NO}_{2}$ over MA-Pt/SA is $74 \%$ and $68 \%$ in the absence and presence of $\mathrm{H}_{2} \mathrm{O}$, respectively, which were much higher than those over C-Pt/SA ( $42 \%$ and $51 \%$ NO conversion with and without $\mathrm{H}_{2} \mathrm{O}$, respectively). Furthermore, the temperature for $30 \% \mathrm{NO}$ conversion over MA-Pt/SA $\left(218{ }^{\circ} \mathrm{C}\right)$ markedly decreased as compared to that over $\mathrm{C}-\mathrm{Pt} / \mathrm{SA}\left(248{ }^{\circ} \mathrm{C}\right)$, indicating the excellent low temperature activity. After the aging treatment with reaction gas at high temperatures, aged MA-Pt/SA maintained 69\% NO conversion while aged C-Pt/SA showed only $41 \%$ NO conversion. In addition, in situ diffuse reflectance infrared Fourier transform spectroscopy (DRIFTS) of $\mathrm{NO}+\mathrm{O}_{2}$ co-adsorption suggested that higher $\mathrm{Pt}$ dispersion and higher $\mathrm{Pt}^{0}$ content over MA-Pt/SA could facilitate the formation of bridging nitrates as intermediate species in NO oxidation at lower temperatures and could also facilitate their rapid decomposition (or desorption) at higher temperatures, thus imparting a high catalytic activity. Furthermore, a decrease in the Pt loading to $0.5 \%(w)$ resulted in a maximum NO conversion of $64 \%$ via the MARI method, suggesting a higher catalytic activity compared to that of C-Pt/SA with $1 \%(w) \mathrm{Pt}$ loading. This work provides a method to prepare highly active Pt-based catalysts with low noble loading.
\end{abstract}

Received: May 5, 2020; Revised: June 3, 2020; Accepted: June 16, 2020; Published online: June 19, 2020.

*Corresponding authors. Emails: wangjianli@scu.edu.cn (J.W.); zhaoming@scu.edu.cn (M.Z.). Tel./Fax: +86-28-85418451 (J.W.).

The project was supported by the National Natural Science Foundation of China (21972098).

国家自然科学基金(21972098)资助项目

(C) Editorial office of Acta Physico-Chimica Sinica 
Key Words: DOC; Modified alcohol reduction-impregnation method; NO oxidation; High-performing Pt catalyst; Low Pt loading

\title{
高分散还原态Pt基催化剂的制备及其NO氧化的催化性能
}

\author{
丁心湄 ${ }^{1}$, 梁艳丽 ${ }^{2}$, 张海龙 ${ }^{3}$, 赵明 $1,{ }^{*}$ ，王健礼 ${ }^{1,}{ }^{*}$ ，陈耀强 1 \\ 1 四川大学化学学院, 绿色化学与技术教育部重点实验室, 成都 610064 \\ 2 四川大学高分子材料工程国家重点实验室, 成都 610064 \\ 3 厦门大学化学与化学工程学院化学系, 福建 厦门 361005
}

\begin{abstract}
摘要: $\mathrm{Pt}^{0}$ 被认为是 $\mathrm{NO}$ 氧化的活性物种, 而催化剂的制备方法对活性物种的含量起着决定性作用。本文采用非惰性气氛 保护的改性醇还原-浸渍法(MARI)合成了高分散高 $\mathrm{Pt}^{0}$ 含量的 $1 \%$ ( $w$, 质量分数) $\mathrm{Pt} / \mathrm{SiO}_{2}-\mathrm{Al}_{2} \mathrm{O}_{3}$ 催化剂(MA-Pt/SA)。X射 线粉末衍射(XRD)、CO-漫反射傅里叶变换红外吸收光谱(CO-DRIFTS)和透射电镜(TEM)表征证实在 $5500^{\circ} \mathrm{C}$ 焙烧 $3 \mathrm{~h}$ 后催 化剂的Pt颗粒仅有 $3.8 \mathrm{~nm}$ 。同时, $X$ 射线光电子能谱 $(X P S)$ 和 $\mathrm{H}_{2}$-程序升温还原 $\left(\mathrm{H}_{2}-\mathrm{TPR}\right)$ 结果表明催化剂具有高 $\mathrm{Pt}^{0}$ 含量 $(60.3 \%)$ 。模拟柴油车尾气气氛进行活性测试, 并与传统浸渍法制备的 $1 \%(w) \mathrm{Pt} / \mathrm{SiO}_{2}-\mathrm{Al}_{2} \mathrm{O}_{3}$ 催化剂(C-Pt/SA)对比, 结 果显示MA-Pt/SA具有优异的催化氧化性能, 其NO最大转化率高达 $74 \%$, 比 C-Pt/SA的NO转化率高了 $23 \%$ 。经 $670{ }^{\circ} \mathrm{C}$ 高 温老化 $15 \mathrm{~h}$ 后, 老化的MA-Pt/SA的NO转化率仍然高达 $69 \%$ 。此外 $N O+\mathrm{O}_{2}$ 共吸附原位漫反射傅里叶变换红外吸收光谱 (in situ DRIFTS of $\mathrm{NO}+\mathrm{O}_{2}$ co-adsorption)表明高的 $\mathrm{Pt}$ 分散度和高 $\mathrm{Pt}{ }^{0}$ 含量能够促进中间物种桥式硝酸盐的生成及分解, 进而导致了优异的 NO氧化活性。最后, 利用同样方法将Pt的负载量降低至 $0.5 \%(w)$ 制备催化剂, NO转化率仍达 $64 \%$ 。 这种制备方法能够获得低贵金属高性能的Pt基催化剂。
\end{abstract}

关键词: 柴油车氧化催化剂; 改性的醇还原-浸渍法; NO氧化; 高性能Pt基催化剂; 低Pt含量 中图分类号：0643

\section{Introduction}

The hazardous gas derived from diesel-engined vehicles consists of unburned hydrocarbons (HC), carbon monoxide (CO), nitrogen monoxide (NO) and particulate matter, and their emissions are the main reason of air pollution ${ }^{1}$. Given more tightened emission standards, the combined after-treatment systems, consisting of diesel oxidation catalyst (DOC), diesel particulate filters (DPF), selective catalytic reduction (SCR) and ammonia slip catalyst (ASC) are used ${ }^{2,3}$. DOC is in the front of after-treatment systems, the function of which is to catalyze the oxidation of $\mathrm{HC}, \mathrm{CO}$ and $\mathrm{NO}$. $\mathrm{NO}$ conversion into $\mathrm{NO}_{2}$ is an important index for evaluating catalytic performances, because $\mathrm{NO}_{2}$ can facilitate soot oxidation in DPF and fast reduction in $\mathrm{SCR}^{4}$. Pt-based catalysts are generally used in exhaust gas aftertreatment system due to its excellent catalytic performance. The related studies had proved that small-size Pt particles had an important effect on improving catalytic performance on account of exposing more surface active sites ${ }^{5,6}$. Many studies have focused on decreasing Pt size to enhance catalytic performance. In our previous work ${ }^{7}$, adding $\mathrm{Mg}$ to Pt-based catalysts by the impregnation method obtained higher $\mathrm{Pt}$ dispersion due to $\mathrm{Pt}-$ $\mathrm{O}-\mathrm{Mg}$ bond formation, but unfortunately the presence of this covalent bond also caused the formation more $\mathrm{PtO}$ which was unfavorable to catalytic reaction for $\mathrm{NO}$ oxidation. Metal $\mathrm{Pt}$ is widely considered as an active specie for the catalysts of exhaust gas while $\mathrm{PtO}_{x}$ formation is responsible for the decreased activity, and thus it's crucial for $\mathrm{Pt}$ catalysts to increase $\mathrm{Pt}^{0}$ content of catalysts at same loading ${ }^{8,9}$. Considering the both factors above, it's necessary to develop new preparation techniques to obtain the Pt catalysts with smaller size of $\mathrm{Pt}$ particles and high $\mathrm{Pt}^{0}$ content.

In recent years, reducing metal salt by various reductants is the broadest method for preparing supported catalysts with nanosized metal particles (Pt, Pd, Rh, Au and so on) ${ }^{10-27}$. García et al. ${ }^{28}$ obtained Pt-based catalysts supported on undoped carbon materials via conventional impregnation technology and $\mathrm{NaBH}_{4}$ reduction method, and the higher activity of hydrodechlorination reactions was observed for the latter. According to the literature reported by Ma and co-workers ${ }^{29}$, the active metal catalyst of ethanol electrooxidation is metal $\mathrm{Pt}$ in acidic media. They used ethylenediamine-tetramethylene phosphonic acid (EDTMP) to coordinate with $\mathrm{H}_{2} \mathrm{PtCl}_{6}$ to form the complex of EDTMP $-\mathrm{Pt}^{\mathrm{IV}}$, and then obtained $\mathrm{Pt}^{0}$ nanoparticles due to self-reduction. The size-controlled $\mathrm{Pt} / \mathrm{C}$ catalyst with $2.5 \mathrm{~nm}$ was prepared by this reduction method and showed the highest ethanol electrooxidation activity. However, this reduction technology is less employed in preparing exhaust purification catalysts.

Here, we combined the modified reduction method with impregnation method, namely the modified alcohol reductionimpregnation (MARI) method, to synthesize supported-Pt DOC with high $\mathrm{Pt}$ dispersion and $\mathrm{Pt}^{0}$ proportion. Firstly, in this method, $\mathrm{H}_{2} \mathrm{PtCl}_{6}$ was completely reduced in ethylene glycol (EG) and water system, with polyvinylpyrrolidone (PVP) as a coating agent to get homogeneously distributed $\mathrm{Pt}^{0}$ 
nanoparticles. Although EG and PVP has been widely reported to synthesis the Pt nanoparticles, the modified reduction process of MARI method is conciser and easier than other reduction methods ${ }^{11,14,30}$, without alkaline/acidic reagents and inert atmosphere, and $\mathrm{Pt}^{0}$ nanoparticles (less than $3 \mathrm{~nm}$ ) could be obtained in $\mathrm{EG} / \mathrm{H}_{2} \mathrm{O}$ solution via controlling reduction conditions. And then, loading the products on $\mathrm{SiO}_{2}-\mathrm{Al}_{2} \mathrm{O}_{3}(\mathrm{SA})$ material by impregnating made Pt nanoparticles homogeneously and individually supported on SA. This spatial distribution of Pt could prevent its particle aggregation at high temperatures. At the same time, the same content of $\mathrm{H}_{2} \mathrm{PtCl}_{6}$ was loaded on SA only using traditional impregnation to obtain $\mathrm{Pt} / \mathrm{SA}$ catalyst as a reference sample.

Notably, the prominent advantage of MARI method is that it can obtain small $\mathrm{Pt}$ particles and high $\mathrm{Pt}^{0}$ content, making the efficient use of precious metal and hence highly boosting the catalytic property of Pt-based catalysts. Moreover, using this method the Pt loading of catalyst was decreased from $1 \%(w)$ to $0.5 \%(w)$, and its catalytic performance was even superior contrast with $1 \%(w)$ Pt sample obtained by conventional impregnation technology, showing that this combined preparative technique is cost-competitive for catalytic application.

At the same time, a series of experiments, including ICP-OES, XPS, XRD, TEM, CO-DRIFTS, $\mathrm{H}_{2}$-TPR and in situ DRIFTS of $\mathrm{NO}+\mathrm{O}_{2}$ co-adsorption, were performed in order to investigate physical and chemical properties of all samples. Our works demonstrated that it is feasible to get cost-efficient and highly active Pt-based catalysts by MARI method.

\section{Experimental section}

\subsection{Catalyst preparation}

For MARI method, as shown by Scheme $1, \mathrm{H}_{2} \mathrm{PtCl}_{6} \cdot 6 \mathrm{H}_{2} \mathrm{O}$ (99.9\%, purity) was firstly reduced through modified reduction process. Polyvinylpyrrolidone (PVP, K30, purity) in ethylene glycol (EG, purity) was mixed with $\mathrm{H}_{2} \mathrm{PtCl}_{6} \cdot 6 \mathrm{H}_{2} \mathrm{O}$ aqueous solution. The mixture was refluxed at $110{ }^{\circ} \mathrm{C}$, dispensing with alkaline/acidic reagents and inert atmosphere, to obtain transparent dark-brown colloidal solution. Then, the PVP-

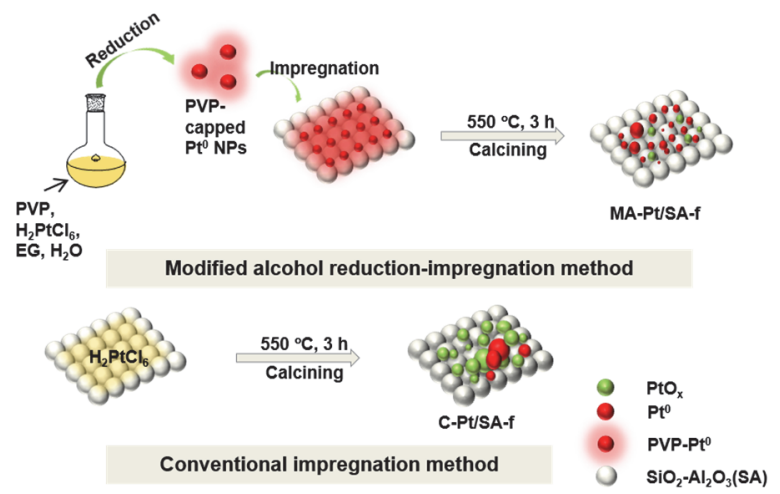

Scheme 1 The diagrammatic drawing of preparation process for two methods. stabilized Pt metal nanoparticles were collected by centrifugation with acetone (purity) and finally redispersed in deionized water. Secondly, the obtained products were supported on $\mathrm{SiO}_{2}-\mathrm{Al}_{2} \mathrm{O}_{3}$ ( $\mathrm{SA}$, provided by Solvay) materials by impregnation method with a total $1 \%(w)$ Pt loading, and this sample was denoted as uncalcined MA-Pt/SA. And then, it was calcined at $550{ }^{\circ} \mathrm{C}$ for $3 \mathrm{~h}$ in static air. The homogeneous slurry was obtained by mixing distilled water with the sample powder, and was wash-coated onto honeycomb cordierite $\left(2.5 \mathrm{~cm}^{3}\right.$, USA) with coat-loading amount of about $150 \mathrm{~g} \cdot \mathrm{L}^{-1}$. The obtained monolithic catalyst and the residual slurry simultaneously was dried at $60^{\circ} \mathrm{C}$, and then calcined again at $550^{\circ} \mathrm{C}$ for $3 \mathrm{~h}$, denoted as MA-Pt/SA-f. After treatments mentioned above, the monolithic catalyst and the catalyst powder (obtained by the residual slurry) was used in catalytic evaluation and catalyst characterization, respectively. The actual Pt loading of the MA$\mathrm{Pt} / \mathrm{SA}$ sample was $0.9727 \%(w)$ tested by ICP-OES, near to the theoretical loading. It indicated that liquid $\mathrm{Pt}$ ions were completely reduced to $\mathrm{Pt}^{0}$ nanoparticles after centrifugation were totally supported on SA materials.

For conventional impregnation method, the aqueous solution of $\mathrm{H}_{2} \mathrm{PtCl}_{6} \cdot 6 \mathrm{H}_{2} \mathrm{O}$ was directly impregnated on $\mathrm{SA}$ by the equal pore volume impregnation method $(1 \%(w) \mathrm{Pt})$ and calcined at $550{ }^{\circ} \mathrm{C}$ for $3 \mathrm{~h}$ in static air. The monolithic catalyst and the powder sample was obtained by the same method above, denoted as C-Pt/SA-f. ICP-OES demonstrated that its actual Pt loading was $0.9692 \%(w)$.

The sample of MA-Pt/SA-f and C-Pt/SA-f undergone the aging treatment (aging condition: $0.15 \% \mathrm{CO}, 0.06 \% \mathrm{C}_{3} \mathrm{H}_{6}$, $0.02 \% \mathrm{NO}, 4 \% \mathrm{CO}_{2}, 5 \% \mathrm{O}_{2}$, and $\mathrm{N}_{2}$ balance, at $670{ }^{\circ} \mathrm{C}$ for $15 \mathrm{~h}$ and then $250^{\circ} \mathrm{C}$ for $15 \mathrm{~h}$ ), and was denoted as MA-Pt/SA-a and $\mathrm{C}-\mathrm{Pt} / \mathrm{SA}-\mathrm{a}$, respectively. Besides, we also synthesized Pt/SA with $0.5 \%(w)$ Pt loading by MARI method, denoted as MA-0.5 $\mathrm{Pt} / \mathrm{SA}$. The actual Pt loading of MA-0.5Pt/SA sample was $0.4740 \%(w)$ proved by ICP-OES.

\subsection{Catalytic evaluation}

The catalytic performance evaluation of all samples was completed in a fixed bed quartz flow reactor. The monolithic catalysts were inserted into quartz tube, and then were placed in the constant temperature zone of a cylindrical furnace. A Kthermocouple was positioned on the top of catalysts to monitor the catalyst bed temperature (presented in this paper). Another $\mathrm{K}$-thermocouple was positioned in a middle place between the quartz tube and the furnace connected with a temperature controller. The reactant gases contained $\mathrm{CO}(0.1 \%), \mathrm{C}_{3} \mathrm{H}_{6}$ $(0.033 \%), \mathrm{NO}(0.02 \%), \mathrm{CO}_{2}(8 \%), \mathrm{O}_{2}(10 \%), \mathrm{N}_{2}$ balance with/without $\mathrm{H}_{2} \mathrm{O}(7 \%)$, GHSV $60000 \mathrm{~h}^{-1}$. The gas flow was controlled by mass flow controllers. Before catalytic performance evaluation, all samples were pre-treated under simulative exhaust gases, including $\mathrm{CO}(0.1 \%), \mathrm{C}_{3} \mathrm{H}_{6}(0.033 \%)$, $\mathrm{NO}(0.02 \%), \mathrm{CO}_{2}(8 \%), \mathrm{O}_{2}(10 \%), \mathrm{N}_{2}$ balance with/without $\mathrm{H}_{2} \mathrm{O}$ (7\%), GHSV $30000 \mathrm{~h}^{-1}$ at $550{ }^{\circ} \mathrm{C}$ for $3 \mathrm{~h}$ to get stable catalysts during the reaction. Nicolet Antaris IGS-6700 gas analyzer 
(Thermo Fisher Scientific, USA) was used to monitor the content of the outlet gas $\left(\mathrm{CO}, \mathrm{C}_{3} \mathrm{H}_{6}\right.$, $\mathrm{NO}$ and $\left.\mathrm{NO}_{2}\right)$. The $\mathrm{CO}$, $\mathrm{C}_{3} \mathrm{H}_{6}$ and $\mathrm{NO}$ conversion were calculated by the following equations:

$$
\begin{aligned}
& \mathrm{CO} \text { conversion }=\left(C_{\mathrm{CO}}^{\text {in }}-C_{\mathrm{CO}}^{\text {out }}\right) / C_{\mathrm{CO}}^{\text {in }} \times 100 \% \\
& \mathrm{HC} \text { conversion }=\left(C_{\mathrm{HC}}^{\text {in }}-C_{\mathrm{HC}}^{\text {out }}\right) / C_{\mathrm{HC}}^{\text {in }} \times 100 \% \\
& \mathrm{NO} \text { conversion }=\left(C_{\mathrm{NO}_{2}}^{\text {out }}-C_{\mathrm{NO}_{x}}^{\text {in }}\right) \times 100 \%
\end{aligned}
$$

\subsection{Catalyst characterizations}

Electron spectrometer (XSAM-800, KRATOS Co., England) was exploited to obtain XPS data with an $\mathrm{Al} K_{\alpha}$ radiation. The binding energies were calibrated by C $1 s(284.6 \mathrm{eV})$. The Rigaku Ultima IV diffractometer were used to obtained the XRD (Rigaku, Japan) patterns employing $\mathrm{Cu} K_{\alpha}$ radiation $(40 \mathrm{kV}, 40$ $\mathrm{mA}, 2 \theta=20^{\circ}-80^{\circ}$, scanning step $\left.=0.02^{\circ}, \lambda=0.15406 \mathrm{~nm}\right)$. The particle size of Pt could be roughly evaluated by Pt (111) FWHM (the full width at half maximum) based on Debye-Scherrer equation: $d=0.89 \lambda /(\beta \cos \theta)$, where $\theta$ is the angle of the peak, $\beta$ is FWHM, $\lambda$ is the wavelength of X-ray. The Pt loading of catalysts was determined by inductively coupled plasma/optical emission spectroscopy (ICP-OES, Perkin-Elmer plasma 8000, USA). Using a tubular quartz micro-reactor with TCD (thermal conductivity detector) collected $\mathrm{H}_{2}$-TPR (TP-5074, China) profiles. The preprocessing of the samples $(0.1 \mathrm{~g})$ were finished by He flow at $450{ }^{\circ} \mathrm{C}$ for $30 \mathrm{~min}$. Whereafter, the samples were reduced by $5.0 \%$ ( $\varphi$, volume fraction) $\mathrm{H}_{2} / \mathrm{N}_{2}$ from ambient temperature to $400{ }^{\circ} \mathrm{C}$ with a heating rate of $8{ }^{\circ} \mathrm{C} \cdot \mathrm{min}^{-1}$.

Transmission electron microscopy (TEM) characterization of all catalysts were completed by Tecnai G2 F20 S-TWIN (FEI Company, US), using an acceleration voltage of $200 \mathrm{kV}$. The distributions of particle size were obtained by the Digital Micrograph software. The equation of the average particle size is as followed:

$$
d=\sum_{i} n_{i} d_{i} / \sum_{i} n_{i}
$$

where $n_{i}$ is the particle number (about 100 particles) and $d_{i}$ is particles diameter.

Besides, according to the reference reported by Peng et al. ${ }^{31}$, the dispersion of $\mathrm{Pt}$ was calculated by the following equations:

$$
D_{\mathrm{Pt}}=600 M_{\mathrm{Pt}} / \rho d a_{\mathrm{Pt}} \mathrm{N}_{\mathrm{A}}
$$

where $M_{\mathrm{Pt}}$ is $195.08 \mathrm{~g} \cdot \mathrm{mol}^{-1}$ (the molar weight of $\mathrm{Pt}$ ); $\rho$ is 21.45 $\mathrm{g} \cdot \mathrm{cm}^{-3}$ (the density of $\mathrm{Pt}$ ); $a_{\mathrm{Pt}}$ is $8.06 \times 10^{-20} \mathrm{~m}^{2} \cdot$ atom $^{-1}$; $N_{\mathrm{A}}$ is $6.02 \times 10^{23} \mathrm{~mol}^{-1}$ (the Avogadro constant); $d$ is the mean size of Pt obtained by TEM.

CO-DRIFTS (diffuse reflectance infrared Fourier transform spectroscopy) experiments were carried out using a DRIFTS spectrometer (Thermo Nicolet 6700, Thermo Scientific, USA), equipped with a reaction cell and $\mathrm{KBr}$ windows. The preconditioning of catalyst powder was accomplished by $\mathrm{N}_{2}$ at $450{ }^{\circ} \mathrm{C}$ for $30 \mathrm{~min}$. The catalyst was cooled to $25^{\circ} \mathrm{C}$ and then contacted with $1 \%(\varphi) \mathrm{CO} / \mathrm{N}_{2}$ until saturation. After that, the CODRIFTS spectra were obtained after $\mathrm{N}_{2}$ purging. The spectra were collected by subtracting atmospheric background and the background of samples without adsorption. Each spectrum was accumulated with a resolution of $4 \mathrm{~cm}^{-1}$ in 64 scans.
$\mathrm{NO}+\mathrm{O}_{2}$ co-adsorption experiments were performed using a DRIFTS spectrometer, similar to CO-DRIFTS (Thermo Nicolet 6700 , Thermo Scientific, USA). The samples were mixed with $\mathrm{KBr}$ with a weight ratio of $1: 20$, and were pretreated in $\mathrm{N}_{2}$ at $450{ }^{\circ} \mathrm{C}$ for $30 \mathrm{~min}$. After cooling, $0.1 \% \mathrm{NO}+10 \%(\varphi) \mathrm{O}_{2}$ in $\mathrm{N}_{2}$ $\left(300 \mathrm{~mL} \cdot \mathrm{min}^{-1}\right)$ were flowed at $50{ }^{\circ} \mathrm{C}$. In situ spectra were recorded at the range of 50 to $300{ }^{\circ} \mathrm{C}$.

\section{Results and discussion 3.1 Surface state of $\mathrm{Pt}$ 3.1.1 XPS}

The Pt valence states are a crucial factor for the catalytic activity. In the light of the reported literature ${ }^{32}$, the possible reaction pathways of $\mathrm{NO}$ oxidation were presented as follows: the gaseous $\mathrm{O}_{2}$ adsorbed on Pt particles and disassociated into atomic oxygen and yielded $\mathrm{Pt}-\mathrm{O}$ component, and then it reacted with gaseous NO (Eley-Rideal model, $\mathrm{Pt}-\mathrm{O}+\mathrm{NO} \rightarrow$ $\mathrm{Pt}-\mathrm{NO}_{2}$ ) or adsorbed NO (Langmuir-Hinshelwood model, Pt$\mathrm{O}+\mathrm{Pt}-\mathrm{NO} \rightarrow \mathrm{Pt}+\mathrm{Pt}-\mathrm{NO}_{2}$ ) to produce $\mathrm{NO}_{2}$. Moreover, the literature ${ }^{9}$ reported that, compared with metal $\mathrm{Pt}^{0}$, the binding ability of $\mathrm{PtO}_{2}$ toward $\mathrm{O}_{2}, \mathrm{O}$ and $\mathrm{NO}$ is weak, and the dissociation of $\mathrm{O}_{2}$ on the oxidized $\mathrm{Pt}$ is pretty hard. Other literature also reported that $\mathrm{Pt}$ oxide formation resulted in the decrease of activity ${ }^{8,33}$. That is, metal Pt is regarded as an active center for NO oxidation reaction ${ }^{8,9}$. So, XPS analyses were performed for revealing the effects of two preparation methods on the chemical state of Pt. Unfortunately, the intensity of Pt $4 d$ peak over two samples is too weak to analyze. Thus, the spectra of $\mathrm{Al} 2 p$ and $\mathrm{Pt} 4 f$ are shown by Fig. 1 (the whole spectra of $\mathrm{Al}$ $2 p$ and $\mathrm{Pt} 4 f$ could be seen as Fig. S1 (in Supporting Information)), and all binding energies were calibrated by $\mathrm{C} 1 \mathrm{~s}$ $(284.6 \mathrm{eV})$. The $\mathrm{Al} 2 p$ core level spectra had no difference over C-Pt/SA-f and MA-Pt/SA-f samples, which were located at about $74.4 \mathrm{eV}$. Though Pt $4 f$ peak was overlapped by Al $2 p$ at $74.4 \mathrm{eV}$, the peaks at $70.9 \mathrm{eV}\left(\mathrm{Pt}^{0}\right), 77.3 \mathrm{eV}\left(\mathrm{Pt}^{2+}\right)$ and $78.2 \mathrm{eV}$ $\left(\mathrm{Pt}^{4+}\right)$ could be observed. The curve-fitting of $\mathrm{Pt} 4 f$ was performed for the quantitative calculation of the Pt chemical states 34,35 . The binding energies of Pt $4 f_{7 / 2}$ and Pt $4 f_{5 / 2}$ were 70.9/74.3 eV, 73.6/77.3 eV, and 74.8/78.2 eV, assigned to $\mathrm{Pt}^{0}$,

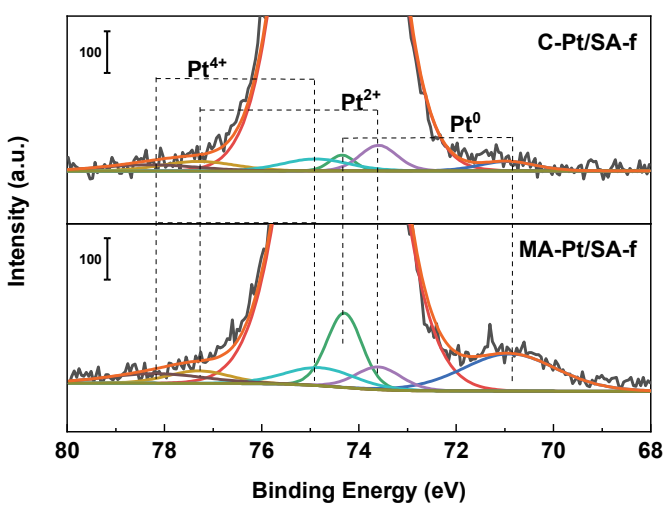

Fig. 1 XPS spectra of Al $2 p$ and Pt $2 p$ for C-Pt/SA-f and MA-Pt/SA-f samples. 
$\mathrm{Pt}^{2+}$ and $\mathrm{Pt}^{4+}$ respectively. Visibly, the peak intensity of MA$\mathrm{Pt} / \mathrm{SA}-\mathrm{f}$ at $70.9 \mathrm{eV}\left(\mathrm{Pt}^{0}\right)$ was stronger than that of C-Pt/SA-f. In other words, the content of metallic Pt over MA-Pt/SA-f markedly increased compared with C-Pt/SA-f. The information involving $\mathrm{Pt}$ species ratio $\left(\mathrm{Pt}^{0}, \mathrm{Pt}^{2+}\right.$ and $\left.\mathrm{Pt}^{4+}\right)$ was presented in Table 1. The $\mathrm{Pt}^{0}$ proportion of MA-Pt/SA-f was about $60.3 \%$, while that of C-Pt/SA-f was about $23.1 \%$. This result also demonstrated that a portion of $\mathrm{Pt}^{0}$ was reoxidized for MA-Pt/SA$\mathrm{f}$ after calcination at $550^{\circ} \mathrm{C}$ in air.

The XPS results showed that the MARI method could obtain $\mathrm{Pt}$ catalysts containing more $\mathrm{Pt}^{0}$ species, which was confirmed by CO-DRIFRS and $\mathrm{H}_{2}$-TPR, efficaciously enhancing the $\mathrm{Pt}$ utilization.

\subsubsection{CO-DRIFTS}

To further investigate the surface states of catalysts, CODRIFTS were performed after $\mathrm{N}_{2}$ pretreatment. According to the intensity and position of $\mathrm{CO}$ absorption bands, surface composition of Pt could be monitored sensitively. Fig. 2 exhibits the DRIFTS spectra of $\mathrm{CO}$ adsorbed on the fresh catalysts at 25 ${ }^{\circ} \mathrm{C}$. It was commonly recognized that the region of 2000-2100 $\mathrm{cm}^{-1}$ over the two samples could be belonging to linearly adsorbed $\mathrm{CO}-\mathrm{Pt}^{0}$. The stretching frequency at about $2122 \mathrm{~cm}^{-1}$ was attributed to $\mathrm{CO}$ adsorbed on $\mathrm{PtO}_{x}{ }^{36}$. Two $\mathrm{CO}$ absorbed bands (a main band at $2079 \mathrm{~cm}^{-1}$ and a weak peak at $2122 \mathrm{~cm}^{-1}$ )

Table 1 XPS data of fresh catalysts.

\begin{tabular}{cccc}
\hline \multirow{2}{*}{ Sample } & \multicolumn{3}{c}{ Relative area ratio (\%) } \\
\cline { 2 - 4 } & $\mathrm{Pt}^{0}$ & $\mathrm{Pt}^{2+}$ & $\mathrm{Pt}^{4+}$ \\
\hline C-Pt/SA-f & 23.1 & 41.9 & 35.0 \\
MA-Pt/SA-f & 60.3 & 17.8 & 21.9 \\
\hline
\end{tabular}

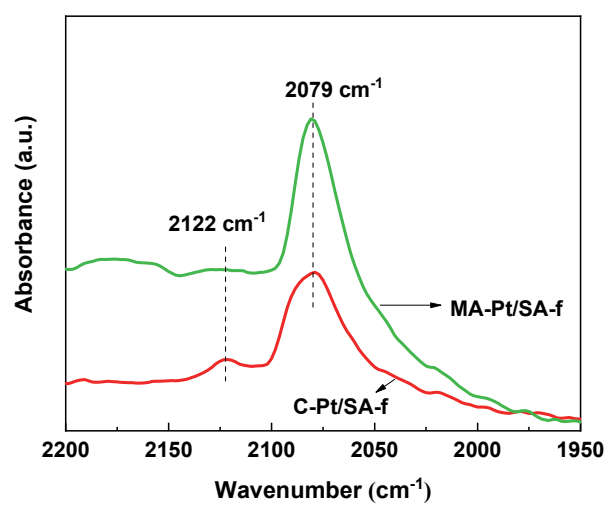

Fig. 2 CO-DRIFTS spectra of fresh samples. in the infrared spectrum were observed over C-Pt/SA-f and MA$\mathrm{Pt} / \mathrm{SA}-\mathrm{f}$, indicating metal $\mathrm{Pt}$ and $\mathrm{Pt}$ oxide exist simultaneously. Moreover, the intensity of $\mathrm{CO}$ adsorption peak at $2122 \mathrm{~cm}^{-1}$ over $\mathrm{C}-\mathrm{Pt} / \mathrm{SA}-\mathrm{f}$ was relatively stronger than that over MA-Pt/SA-f, whereas the intensity of peak at $2079 \mathrm{~cm}^{-1}$ for MA-Pt/SA-f was higher. This result illustrated that MA-Pt/SA-f had more Pt metallic states than C-Pt/SA-f, which was one of reasons for outstanding catalytic activity of Pt catalysts. This is in good agreement with XPS results.

\subsection{Particles size of $\mathbf{P t}$}

\subsubsection{XRD}

Besides the Pt valence state, the structure of catalysts has significant influence on catalytic performance. Here, XRD technology was used to investigate the structure of all catalysts. As shown in Fig. 3 , the diffraction peaks at $45.8^{\circ}$ and $66.8^{\circ}$ were assigned to $\gamma-\mathrm{Al}_{2} \mathrm{O}_{3}$. Beyond that, the XRD analysis revealed typical Pt (111), Pt (200) and Pt (220) crystallographic planes at $2 \theta$ angles $39.8^{\circ}, 46.2^{\circ}$ and $67.5^{\circ}$, respectively. XRD patterns show that the diffraction pattern peak intensity of Pt (111) over all catalysts was different.

For fresh samples, the peak of Pt (111) over MA-Pt/SA-f was broad with low intensity, while the peak of it over C-Pt/SA-f was sharp and strong, suggesting that the Pt particles size over MA$\mathrm{Pt} / \mathrm{SA}-\mathrm{f}$ was smaller. In the light of Debye-Scherrer equation, the Pt size of C-Pt/SA-f and MA-Pt/SA-f was 27.5 and $8.2 \mathrm{~nm}$, respectively (listed in Table 2). In MARI method, EG was employed as a mild reducing agent. Teranishi et al. had proved that the type of alcohol could greatly affect the size of $\mathrm{Pt}$ particles, which decreased with the boiling points of alcohol increasing in alcohol/water system, by comparing methanol,

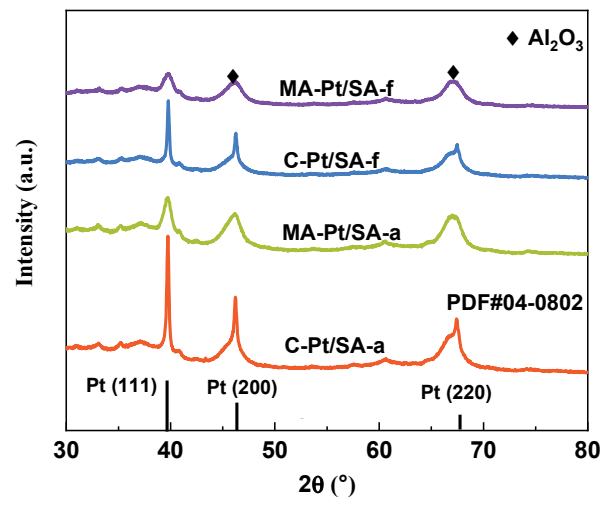

Fig. 3 XRD patterns of all catalysts.

Table 2 The detail results of TEM and NO oxidation over different samples.

\begin{tabular}{|c|c|c|c|c|c|c|c|}
\hline \multirow{2}{*}{ Catalyst } & \multirow{2}{*}{ Pt size (nm) } & \multirow{2}{*}{ Pt dispersion ${ }^{\mathrm{c}}(\%)$} & \multicolumn{2}{|c|}{$T_{50} / T_{90}\left({ }^{\circ} \mathrm{C}\right)$} & \multirow{2}{*}{ NO Max conversion (\%) } & \multirow{2}{*}{ Temperature $\left({ }^{\circ} \mathrm{C}\right)^{\mathrm{d}}$} & \multirow{2}{*}{ TOF $\left(\mathrm{s}^{-1}\right)$} \\
\hline & & & $\mathrm{CO}$ & $\mathrm{HC}$ & & & \\
\hline C-Pt/SA-f & $27.5^{\mathrm{a}} / 7.8^{\mathrm{b}}$ & 14.5 & $221 / 236$ & $229 / 237$ & 51 & 248 & $0.06^{\mathrm{e}}$ \\
\hline MA-Pt/SA-f & $8.2^{\mathrm{a} / 3.8^{\mathrm{b}}}$ & 29.6 & $197 / 209$ & $208 / 212$ & 74 & 218 & $0.22^{\mathrm{e}}$ \\
\hline C-Pt/SA-a & $34.1^{\mathrm{a}} / 9.2^{\mathrm{b}}$ & 12.3 & $233 / 248$ & $245 / 253$ & 41 & 278 & $0.03^{\mathrm{f}}$ \\
\hline MA-Pt/SA-a & $9.5^{\mathrm{a} / 5.1} \mathrm{~b}^{\mathrm{b}}$ & 22.0 & $204 / 217$ & $215 / 222$ & 69 & 226 & $0.21^{\mathrm{f}}$ \\
\hline
\end{tabular}

${ }^{\mathrm{a}} \mathrm{Pt}$ size was obtained by XRD; ${ }^{\mathrm{b}} \mathrm{Pt}$ size was obtained by TEM; ${ }^{\mathrm{c}}$ The dispersion of Pt was obtained by TEM results; ${ }^{\mathrm{d}}$ The temperature of $30 \%$ NO conversion; 

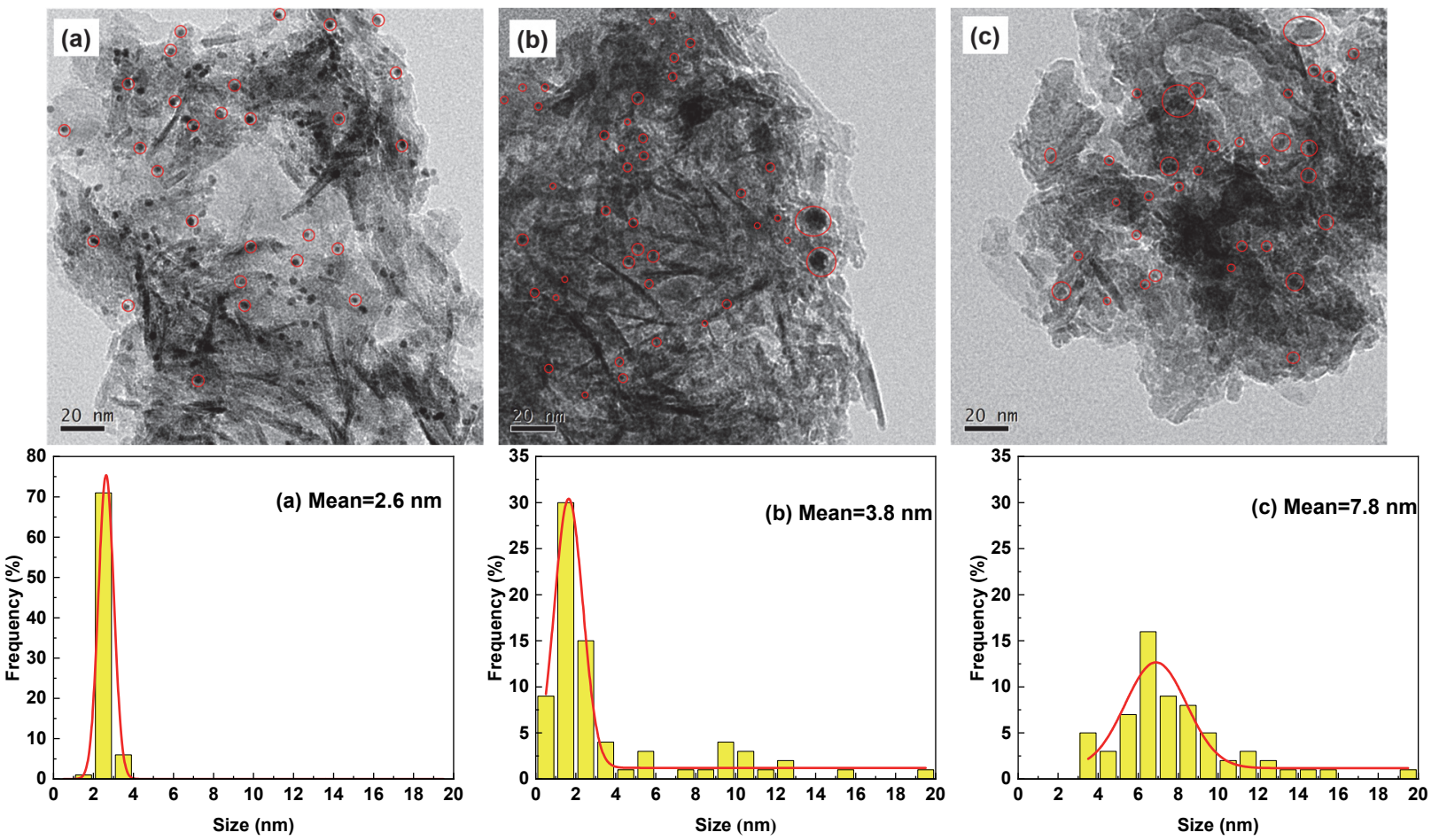

Fig. 4 TEM images and size distribution of Pt nanoparticles over uncalcined MA-Pt/SA (a), MA-Pt/SA-f (b) and C-Pt/SA-f (c) catalysts.

ethanol and 1-propanol ${ }^{10}$. Therefore, EG with high boiling points was used as a reductant for reducing $\mathrm{Pt}^{4+}$ ions to $\mathrm{Pt}^{0}$. Besides, in this process, Pt nuclei firstly formed when reaching a critical point, after that the nucleation and particle growth of $\mathrm{Pt}$ simultaneously occurred ${ }^{37,38}$. Adjusting the reaction conditions made the $\mathrm{Pt}^{4+}$ ions be instantly reduced in a short time and formed more Pt nuclei. That is, the nucleation rate was higher than the rate of particles growth, which could get smaller Pt nanoparticle.

The XRD patterns of aged samples were also shown. And the diffraction peaks corresponding to $\gamma-\mathrm{Al}_{2} \mathrm{O}_{3}$ had no obvious change before and after aging, indicating that it was stable support material because it was pretreated at $1000{ }^{\circ} \mathrm{C}$ for $4 \mathrm{~h}$. Inversely, the intensity of $\mathrm{Pt}$ (111) phase increased in the aged samples, which revealed a certain degree of the aggregation of platinum particles. Observingly, the peak intensity of Pt (111) over MA-Pt/SA-a was weaker than that over C-Pt/SA-f, suggesting that the Pt particles over the aged MARI-obtained sample were also smaller than that over fresh impregnationprepared sample.

\subsubsection{TEM}

The transmission electron microscopy (TEM) micrograph and the Pt size distribution histogram, obtained by counting about $100 \mathrm{Pt}$ nanoparticles, were shown in Fig. 4. The corresponding mean size and dispersion of Pt particles were listed in Table 2. Fig. $4 \mathrm{c}$ shows that the average size of Pt particles over C-Pt/SAf was $7.8 \mathrm{~nm}$ and the size distribution was broad, revealing that its particle size was bigger and not uniform. The Pt particles of uncalcined MA-Pt/SA catalyst were homogeneously and individually dispersed on the surface of supports, and the mean size was about $2.6 \mathrm{~nm}$, as shown by Fig. 4a. This phenomenon demonstrated that the reduction condition of MARI method could control the synthesis of small-sized and uniform $\mathrm{Pt}$ nanoparticles $(<3 \mathrm{~nm})$ via adjusting the nucleation rate and the growth rate. And the impregnation process made $\mathrm{Pt}$ nanoparticles supported on SA singly as shown by Scheme 2 . Here, PVP, with functional groups including $\mathrm{C}-\mathrm{N}, \mathrm{C}=\mathrm{O}$ and $\mathrm{CH}_{2}$, could coordinated with $\mathrm{Pt}^{4+}$ ions by the $\mathrm{O}$ and/or $\mathrm{N}$ atom of the repeating unit ${ }^{10}$. And then, $\mathrm{Pt}^{4+}$ ions were reduced to $\mathrm{Pt}^{0}$ in alcohol/water system and thus yielded PVP-protected $\mathrm{Pt}^{0}$ nanoparticles. Here, the $\mathrm{O}$ atoms of the carbonyl group or $\mathrm{N}$ atoms of PVP still coordinated with surface Pt atoms ${ }^{39,40}$. Simultaneously, its carbon chains were hydrophobic and had the repulsive forces thus resulting in the steric hindrance effect, thus preventing Pt nanoparticles aggregation.

For MA-Pt/SA, it could be discovered that the Pt particle size changed before and after calcination. Fig. $4 \mathrm{~b}$ presents that the metal particle size raised in certain degree after calcining process, and the mean size of Pt over MA-Pt/SA-f was $3.8 \mathrm{~nm}$. This is because the PVP capping layer would decompose above $300{ }^{\circ} \mathrm{C}$, and then the aggregation of Pt particles occurred on account of high-temperature calcination. Notably particularly,

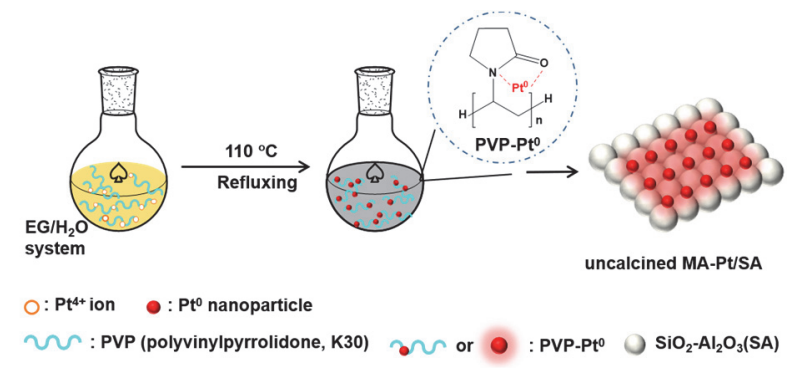

Scheme 2 The diagrammatic drawing of MARI preparation process. 
most of Pt particle size over MA-Pt/SA-f catalyst was primarily in the range of 2-3 nm, which still was smaller compared with C-Pt/SA-f catalyst $(7.8 \mathrm{~nm})$. As shown by Table 2 , the $\mathrm{Pt}$ dispersion of MA-Pt/SA-f and C-Pt/SA-f catalyst was $29.6 \%$ and $14.5 \%$, respectively.

At the same time, the size distribution of Pt on the aged samples was also analyzed. Fig. S2a,b (in Supporting Information) exhibit that the size of the obtained metal particles in MA-Pt/SA-a and C-Pt/SA-a catalyst was 5.1 and $9.2 \mathrm{~nm}$, respectively. Here, the Pt particles over MA-Pt/SA were far apart, which leaded to less sintering during aging process basing on sintering mechanisms of Ostwald ripening as well as particle migration and coalescence ${ }^{41}$.

Besides, there was a difference in Pt sizes obtained by XRD and TEM, because that the testing principles of two characterization techniques are different. Anyhow, whether XRD or TEM results showed that MARI strategy could get the supported Pt catalysts with smaller particles compared with the impregnation process.

\subsection{Redox properties}

$\mathrm{H}_{2}$-TPR tests were performed on all catalysts to investigate the redox property, and the TPR profiles were shown in Fig. 5. It is found that the species of various platinum oxides were reduced below $500{ }^{\circ} \mathrm{C}$ without the reduction of SA material. For fresh sample, the differences in the temperature and area of reduction peak over two samples were observed. The reduction peak temperature of MA-Pt/SA-f $\left(123^{\circ} \mathrm{C}\right)$ turned out to be lower than that of C-Pt/SA-f $\left(136{ }^{\circ} \mathrm{C}\right)$. Previous studies reported that the smaller particle size of platinum oxides would be related the reduction at lower temperature ${ }^{42}$. Therefore, the lower reduction temperature of $\mathrm{PtO}_{x}$ over MA-Pt/SA-f was due to the smaller Pt size verified by TEM and XRD. Besides, as shown in Table S1 (in Supporting Information), the total area of $\mathrm{PtO}_{x}$ reduction peak for C-Pt/SA-f (2684) was approximately 1.6 times than that for MA-Pt/SA-f (1691). Especially at higher temperature, there were obvious differences in reduction peak area between MAPt/SA-f and C-Pt/SA-f. Negligible peak area was shown at 250$400{ }^{\circ} \mathrm{C}$ for MA-Pt/SA-f, while the large peak area was shown at same temperature range for C-Pt/SA-f. This result indicated that more $\mathrm{PtO}_{x}$ species existed in C-Pt/SA-f, consistent with the results of XPS which demonstrated that the $\mathrm{PtO}_{x}$ ratios of CPt/SA-f and MA-Pt/SA-f were $76.9 \%$ and $39.7 \%$ respectively. Additionally, similar phenomenon was also observed in two aged samples. However, the temperature and area of peak over aged catalysts increased compared with fresh catalysts, which might be due to bigger and more $\mathrm{PtO}_{x}$ particles formed under aging conditions. Combining with the other characterization results (XPS/CO-DRIFTS and TEM/XRD), the $\mathrm{H}_{2}$-TPR results suggested that the catalysts synthesized by the MARI method had less $\mathrm{PtO}_{x}$ species and exhibited low-temperature redox property resulting from the smaller Pt size, which could promote the catalytic performance.

\subsection{CO, HC and NO catalytic performance}

The catalytic performances of MA- and C-Pt/SA catalysts for $\mathrm{CO}, \mathrm{C}_{3} \mathrm{H}_{6}$ and $\mathrm{NO}$ oxidation were evaluated in the simulated diesel atmosphere. The conversion curves of $\mathrm{CO}$ and $\mathrm{C}_{3} \mathrm{H}_{6}$ oxidation were shown in Fig. 6a, b, respectively. It could be seen that, whether fresh samples or aged samples, MA-Pt/SA catalyst displayed better activity compared to C-Pt/SA at the same $\mathrm{Pt}$ loading. On the one hand, in order to easily compare the activities data of $\mathrm{CO}$ and $\mathrm{C}_{3} \mathrm{H}_{6}$ oxidation, $T_{50}$ and $T_{90}$ (the temperatures for $50 \%$ and $90 \%$ conversion) of $\mathrm{CO}$ and $\mathrm{C}_{3} \mathrm{H}_{6}$ were shown in Table 2. For the fresh samples, it could be seen that the $T_{50}$ of $\mathrm{CO}$ and $\mathrm{C}_{3} \mathrm{H}_{6}$ for MA-Pt/SA-f sample decreased by $20{ }^{\circ} \mathrm{C}$ compared to that for $\mathrm{C}-\mathrm{Pt} / \mathrm{SA}-\mathrm{f}$ sample. Besides, the $T_{90}$ of $\mathrm{CO}$ and $\mathrm{C}_{3} \mathrm{H}_{6}$ in MA-Pt/SA-f was about $210^{\circ} \mathrm{C}$, while the $T_{90}$ of that in C-Pt/SA-f was about $240{ }^{\circ} \mathrm{C}$. According to the results of activity tests, it demonstrated that MA-Pt/SA-f had excellent low-temperature oxidation properties, in accord with $\mathrm{H}_{2}$-TPR. For the aged samples, the decrease of reaction activity for $\mathrm{CO}$ and $\mathrm{C}_{3} \mathrm{H}_{6}$ oxidation was observed. But, MA-Pt/SA-a still had a better lower-temperature reactivity than C-Pt/SA-a, completely removing $\mathrm{CO}$ and $\mathrm{C}_{3} \mathrm{H}_{6}$ at a temperature about $220^{\circ} \mathrm{C}$.

On the other hand, the results of NO oxidation over all samples were illustrated in Fig. 6c and Table 2. In this work, NO oxidation into $\mathrm{NO}_{2}$ was controlled by thermodynamics, but this reaction was affected by other reactants under simulated diesel conditions. The presence of $\mathrm{C}_{3} \mathrm{H}_{6}$ and $\mathrm{CO}$ could suppress $\mathrm{NO}$ oxidation due to competitive adsorption of active sites, and simultaneously lead to $\mathrm{N}_{2} \mathrm{O}$ formation by reducing $\mathrm{NO}$.
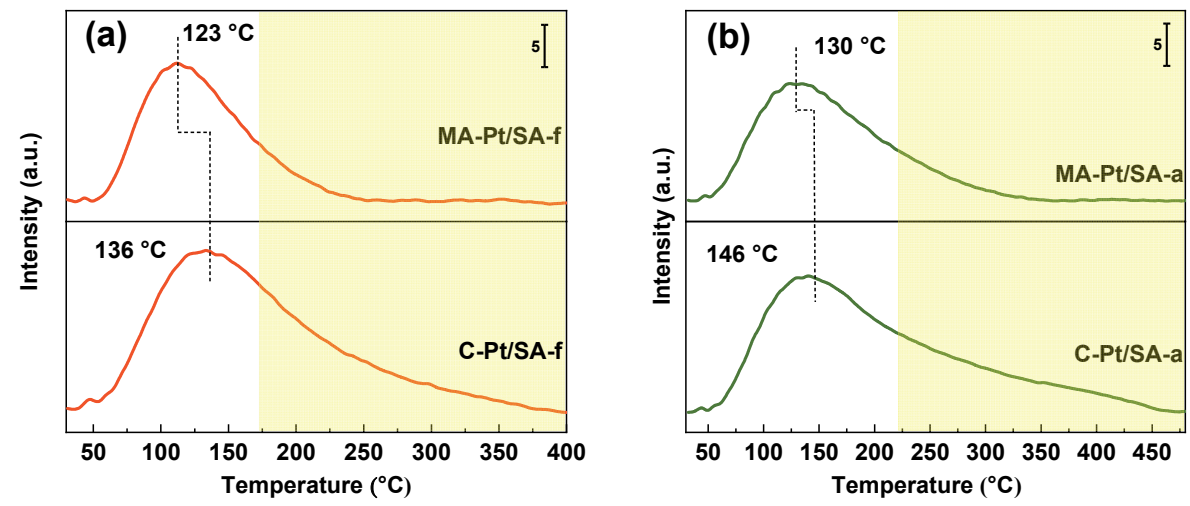

Fig. $5 \mathrm{H}_{2}$-TPR profiles of fresh (a) and aged (b) samples. 

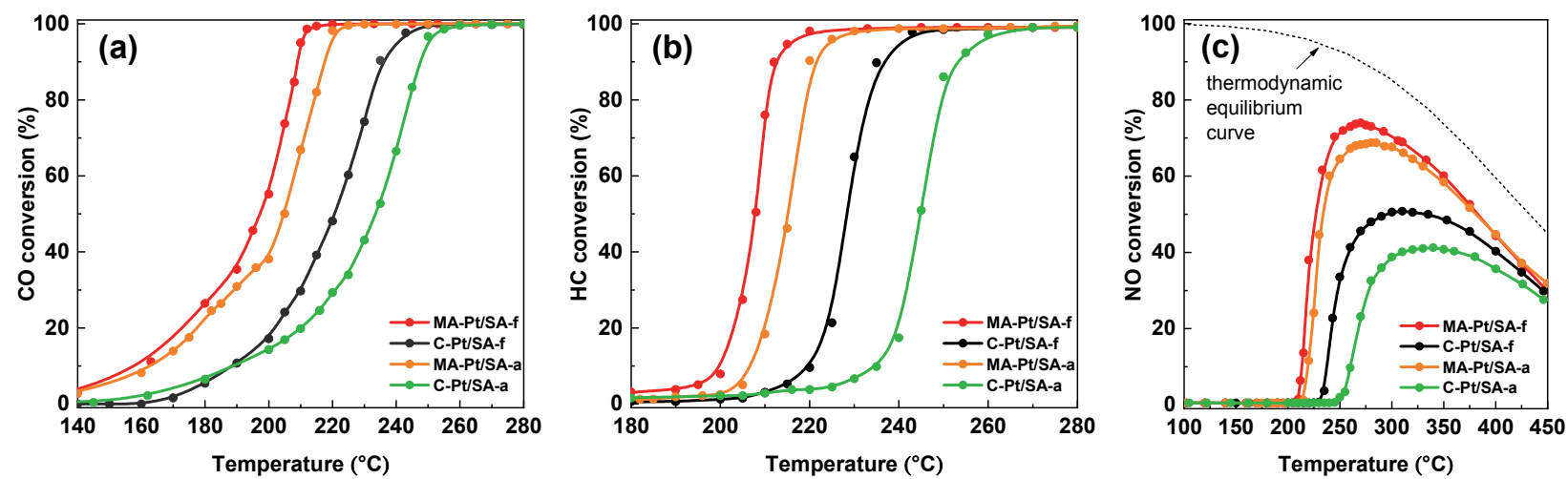

Fig. $6 \mathrm{CO}$ (a), $\mathrm{HC}$ (b) and NO conversion (c) of all catalysts without $\mathrm{H}_{2} \mathrm{O}$.

Therefore, the $\mathrm{NO}$ conversion into $\mathrm{NO}_{2}$ didn't reached the thermodynamic equilibrium even at high temperature, as shown by Fig. S3 (in Supporting Information). It turned out that MA$\mathrm{Pt} / \mathrm{SA}-\mathrm{f}$ was greatly more active than C-Pt/SA-f for the oxidation of NO. The maximum NO conversion of MA-Pt/SA-f could reach up to $74 \%$ at about $265{ }^{\circ} \mathrm{C}$, while that of C-Pt/SA-f was about $51 \%$ at about $310{ }^{\circ} \mathrm{C}$. Furthermore, the temperature of $30 \%$ NO conversion over MA-Pt/SA-f $\left(218{ }^{\circ} \mathrm{C}\right)$ markedly decreased compared with C-Pt/SA-f $\left(248{ }^{\circ} \mathrm{C}\right)$. Based on the Pt dispersion, the turnover frequency (TOF) of NO oxidation, which was defined as the number of $\mathrm{NO}$ molecules converted per active site per second, was calculated to explore the intrinsic activity of NO oxidation (the detail information could be seen in supporting information). In Table 2, the TOF value of MAPt/SA-f with smaller Pt particles $\left(0.22 \mathrm{~s}^{-1}\right)$ was almost 4 times higher than that of C-Pt/SA-f with higher Pt particles $\left(0.06 \mathrm{~s}^{-1}\right)$ at $212{ }^{\circ} \mathrm{C}$. Besides, the influence of $\mathrm{H}_{2} \mathrm{O}$ on catalytic activity of NO oxidation was also investigated. As shown by Fig. S4 (in Supporting Information), the maximum NO conversion of MAPt/SA-f was $68 \%$ in the simulated diesel atmosphere with $7 \%$ $\mathrm{H}_{2} \mathrm{O}$, which increased by $26 \%$ compared with C-Pt/SA-f (42\%). Additionally, Pt-based catalysts for NO oxidation reported in literature were compared with our results, as shown in Table S2 (in Supporting Information). After aging treatment in reaction gas at high temperature, the maximum NO conversion of MA$\mathrm{Pt} / \mathrm{SA}$-a yet could reach up to $69 \%$, while that of C-Pt/SA-a was only $41 \%$. All experimental results above indicated that MA-
$\mathrm{Pt} / \mathrm{SA}$ catalyst had the outstanding low-temperature activity and high NO conversion due to its high $\mathrm{Pt}$ dispersion and $\mathrm{Pt}^{0}$ content.

\subsection{Effect of particle size and valence state of Pt on NO oxidation activity}

The $\mathrm{NO}+\mathrm{O}_{2}$ co-adsorption experiments were performed by in situ DRIFTS at $50{ }^{\circ} \mathrm{C}$, for detecting the formation $\mathrm{NO}_{x}$ species over MA-Pt/SA-f and C-Pt/SA-f. In Fig. 7, the bands at the range of $1700-1200 \mathrm{~cm}^{-1}$ for fresh samples could be ascribed to different nitrates and nitrites species. The band at 1634 and 1540 $\mathrm{cm}^{-1}$ were associated with bridging nitrates and monodenate nitrates, respectively ${ }^{43,44}$. The band at $1520 \mathrm{~cm}^{-1}$ was assigned to the coordinate nitrites ${ }^{43}$. A weak band at $1433 \mathrm{~cm}^{-1}$ could be ascribed to the monodentate nitrites ${ }^{44-46}$. Besides, the two bands at 1395 and $1369 \mathrm{~cm}^{-1}$ were belonged to the asymmetric ionic nitrates, with a shoulder at $1324 \mathrm{~cm}^{-1}$ corresponding to the bridging nitrites ${ }^{45,47}$. For MA-Pt/SA-f, as shown in Fig. 7A, after $1 \mathrm{~min}$ of $\mathrm{NO}+\mathrm{O}_{2}$ co-adsorption, a strong band at $1634 \mathrm{~cm}^{-1}$ (the bridged nitrates) was observed, together with two relatively weak bands at 1540 and $1520 \mathrm{~cm}^{-1}$ (the monodenate nitrates and coordinate nitrites). Additionally, the extremely weak and broad peaks were also observed, related to the coordinate nitrites, asymmetric ionic nitrates and bridged nitrites. As the increased adsorption time, the variation of the band intensity belonging to the bridged nitrates was different from other nitrates or nitrites. The band intensity of bridged nitrates reached to maximum after $5 \mathrm{~min}$ and then began to decrease, while the band intensity of other nitrogen oxides gradually increased with increasing
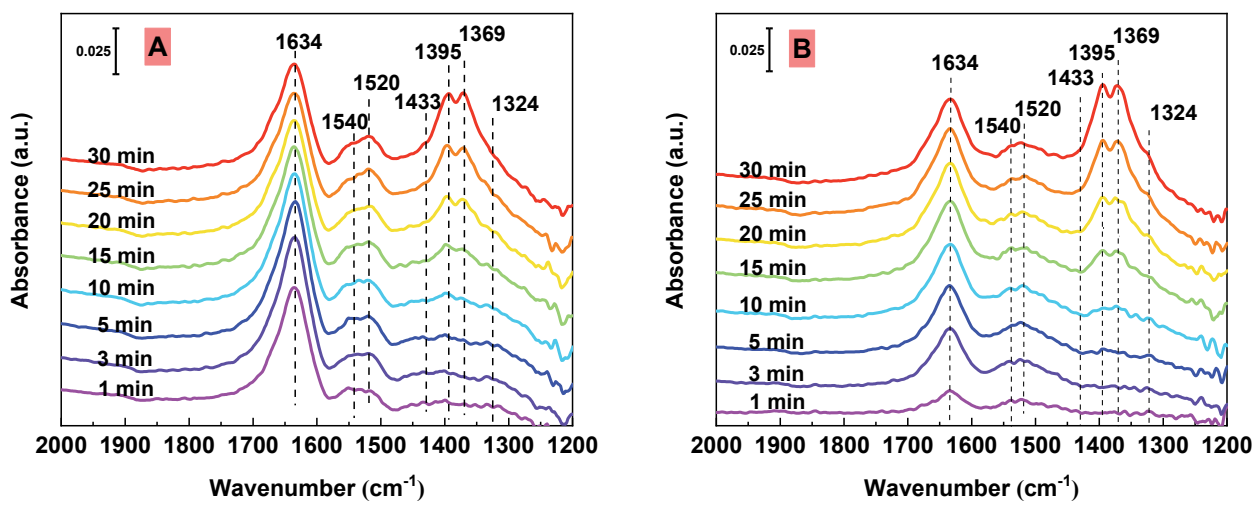

Fig. 7 In situ DRIFTS spectra of $\mathrm{NO}+\mathrm{O}_{2}$ co-adsorption of MA-Pt/SA-f (A) and C-Pt/SA-f (B) in different adsorption time at $50{ }^{\circ} \mathrm{C}$. 
contact time. The DRIFTS spectra of $\mathrm{NO}+\mathrm{O}_{2}$ co-adsorption over C-Pt/SA-f were shown in Fig. 7B, the bands of which were similar with that of MA-Pt/SA-f although the intensity of these bands was diverse. After 1 min of adsorption, the bands of the bridging nitrates, monodenate nitrates and coordinate nitrites were presented, and no bands at $1450-1250 \mathrm{~cm}^{-1}$ could be observed. Visibly, the band intensity corresponding to the bridging nitrates over C-Pt/SA-f was greatly lower than MA$\mathrm{Pt} / \mathrm{SA}-\mathrm{f}$, while the band intensity involving monodenate nitrates and coordinate nitrites over two samples was analogous. After $10 \mathrm{~min}$, the monodentate and bridging nitrites (at 1433 and 1324 $\mathrm{cm}^{-1}$ ) were presented, along with the ionic nitrates (at 1395/1369 $\mathrm{cm}^{-1}$ ). Unlike MA-Pt/SA-f, the intensity of all bands increased with exposure time and reached up to maximum at $30 \mathrm{~min}$. Besides, it's noteworthy that the band intensity of bridging nitrates over C-Pt/SA-f still was lower than MA-Pt/SA-f after 20 $\mathrm{min}$, but the intensity of asymmetric ionic nitrates over C-Pt/SAf was higher than MA-Pt/SA-f.

Our previous work ${ }^{43}$, by comparing PtPd/SA with different particle size ( 9.9 and $16.5 \mathrm{~nm}$ ), proved that the formation of the bridging nitrates could be liable to take place on smaller particles while ionic nitrates were easier to form on larger particles. Considering the experimental results mentioned above including XRD, TEM and CO-DRIFTS, it could be proposed that the smaller Pt particles over MA-Pt/SA-f led to the increased amount of bridging nitrates, which was good for NO oxidation. Moreover, according to the literature ${ }^{48}$, introducing $\mathrm{Pt}$ into $\mathrm{TiO}_{2}$ could facilitate the formation of surface nitrate species. Ji and

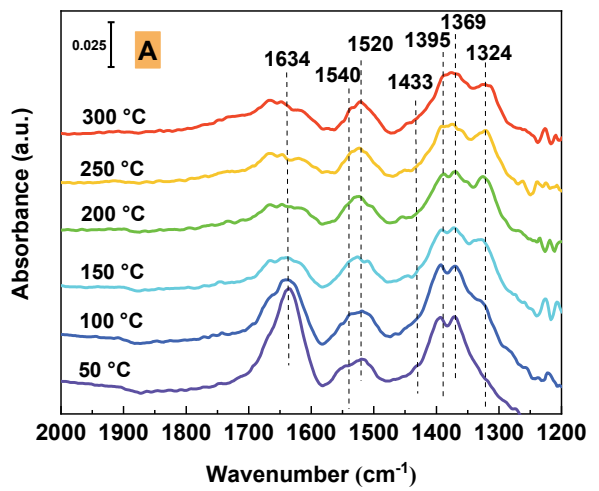

co-workers, by contrasting pre-oxidized and pre-reduced $\mathrm{Pt} / \mathrm{Al}_{2} \mathrm{O}_{3}$, proposed that the amount of nitrates and $\mathrm{NO}_{2}$ could be improved on $\mathrm{Pt}^{0}$ sites compared to $\mathrm{PtO}_{x}{ }^{44}$. In the light of the XPS and CO-DRIFTS, which confirmed that MA-Pt/SA-f had high $\mathrm{Pt}^{0}$ content and exposed more Pt sites, it could conclude that more surface nitrates, as intermediate products, could adsorb on MA-Pt/SA-f due to the smaller Pt particles and high $\mathrm{Pt}^{0}$ proportion at lower temperatures, compared to C-Pt/SA-f.

After the same adsorption time (30 min) over C- and MA$\mathrm{Pt} / \mathrm{SA}-\mathrm{f}$ at $50{ }^{\circ} \mathrm{C}$, in situ DRIFTS spectra were recorded at elevated temperatures from $50{ }^{\circ} \mathrm{C}$ to $300{ }^{\circ} \mathrm{C}$, as shown in Fig. 8 A,B. For MA-Pt/SA-f, during raising temperature, the intensity of bands at the range of $1700-1600 \mathrm{~cm}^{-1}$ involving the bridging nitrates progressively declined. This phenomenon might be owing to that nitrates decomposed and produced $\mathrm{NO}_{2}{ }^{49}$. The bands intensity of $1450-1250 \mathrm{~cm}^{-1}$ presented a slight decrease from $50{ }^{\circ} \mathrm{C}$ to $300{ }^{\circ} \mathrm{C}$, indicating that the asymmetric ionic nitrates and bridging nitrites transformed in part into other $\mathrm{N}_{x} \mathrm{O}_{y}$ species. For C-Pt/SA-f, the intensity of those bands (bridging nitrates, ionic nitrates and bridging nitrites) also decreased with increasing temperature. Moreover, it was a remarkable fact that the amount of bridging nitrates adsorbed on MA-Pt/SA-f was distinctly more than C-Pt/SA-f before $200{ }^{\circ} \mathrm{C}$. However, when the temperature rose up to $200{ }^{\circ} \mathrm{C}$, their amount over two samples almost had no difference. In brief, these results revealed that MA-Pt/SA-f with small $\mathrm{Pt}$ size and high $\mathrm{Pt}^{0}$ proportion facilitated the formation of bridging nitrates as intermediate species for $\mathrm{NO}$ oxidation at lower temperatures, as well as rapid

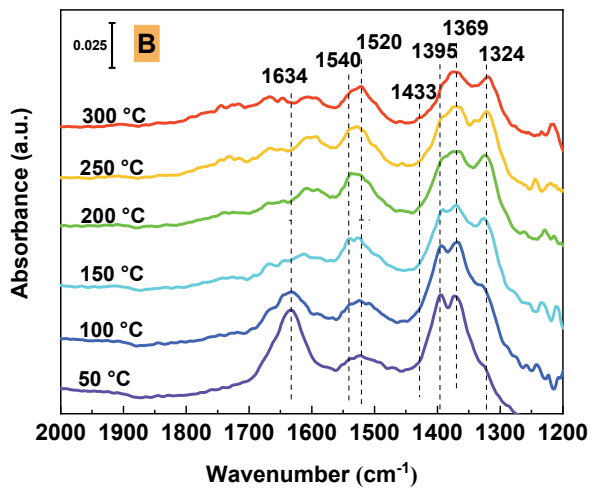

Fig. 8 In situ DRIFTS spectra of $\mathrm{NO}+\mathrm{O}_{2}$ co-adsorption of MA-Pt/SA-f (A) and C-Pt/SA-f (B) at different temperature.
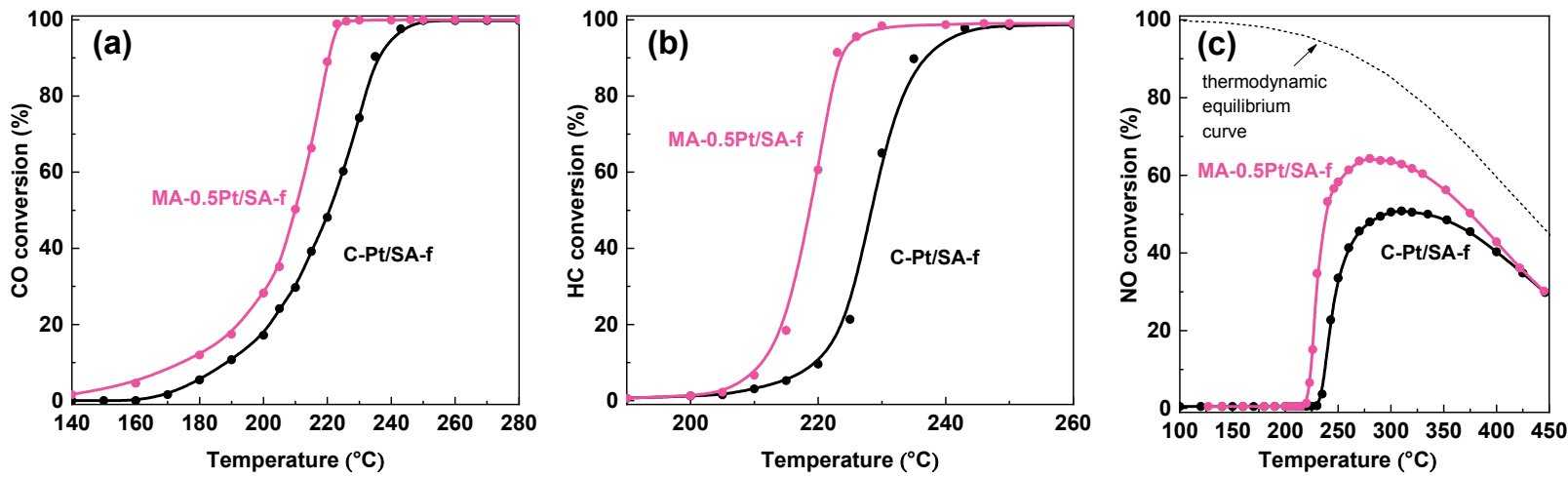

Fig. $9 \mathrm{CO}$ (a), HC (b) and NO (c) conversion of MA-0.5Pt/SA-f and C-Pt/SA-f without $\mathrm{H}_{2} \mathrm{O}$. 
decomposition (or desorption) of those at higher temperatures, bringing about an outstanding NO oxidation activity.

\subsection{Reaction activity of MA-0.5Pt/SA-f}

Meanwhile, MA-0.5Pt/SA-f was prepared and was compared with C-Pt/SA-f. The results of activity evaluation of two fresh samples could be seen in Fig. 9 and Table S3 (in Supporting Information). It was found that, although the loading of noble metal was reduced by a half, the $T_{50}$ and $T_{90}$ of $\mathrm{CO}$ or $\mathrm{C}_{3} \mathrm{H}_{6}$ conversion over MA-0.5Pt/SA-f reduced by $10-15{ }^{\circ} \mathrm{C}$, contrasted with $\mathrm{C}-\mathrm{Pt} / \mathrm{SA}-\mathrm{f}$. For another one, the maximum conversion of NO over MA-0.5Pt/SA-f was $64 \%$, which was obviously higher than that of C-Pt/SA-f. The phenomena mentioned above denoted that the MARI approach was able to greatly decrease the loading of Pt-based catalysts, simultaneously showing better catalytic performance.

\section{Conclusions}

In this work, the modified alcohol reduction-impregnation method was utilized to obtain high-performance Pt-based catalysts. XPS, CO-DRIFTS and $\mathrm{H}_{2}$-TPR analysis indicated that the MARI method could get Pt catalysts with more active centers. Meanwhile, the results of XRD and TEM revealed that this synthetic technology could availably synthesize the Pt/SA catalyst with small Pt size and promote the efficacious utilization of $\mathrm{Pt}$ as well as enhance catalytic performance, compared to the traditional impregnation method. The maximum NO conversion of MA-Pt/SA-f reached up to $74 \%$, which increased by $23 \%$ compared to C-Pt/SA-f without $\mathrm{H}_{2} \mathrm{O}$. After aging, MA-Pt/SA-a still had a pretty good catalytic performance $(69 \%$ NO conversion). In presence of $7 \% \mathrm{H}_{2} \mathrm{O}$, the maximum $\mathrm{NO}$ conversion of MA-Pt/SA-f was $68 \%$. In addition, we prepared MA- $0.5 \mathrm{Pt} / \mathrm{SA}-\mathrm{f}$ sample, and its NO conversion was $64 \%$ which still higher than that of C-Pt/SA-f (51\%). Besides, in situ DRIFTS of $\mathrm{NO}+\mathrm{O}_{2}$ co-adsorption revealed that the smaller Pt particles and higher $\mathrm{Pt}^{0}$ content over MA-Pt/SA-f facilitated the formation of bridging nitrates as intermediate species for $\mathrm{NO}$ oxidation at lower temperature, as well as rapid decomposition (or desorption) of those at higher temperature, bringing about an outstanding NO oxidation activity. Here, this work showed that MARI method could apparently improve the catalytic activity of Pt-based catalyst even for lower loading of Pt. This method is significantly important for preparing highly active Pt catalysts with lower Pt loadings.

Acknowledgment: We would like to thank the Analytical \& Testing Center of Sichuan University for XPS work of Dr. Suilin Liu.

Supporting Information: available free of charge via the internet at http://www.whxb.pku.edu.cn.

\section{References}

(1) Russell, A.; Epling, W. S. Catal. Rev. 2011, 53, 337. doi: $10.1080 / 01614940.2011 .596429$

(2) Johnson, T.; Joshi, A. SAE Int. Eng. 2018, 11, 1307. doi: 10.4271/2018-01-0329

(3) Koebel, M.; Elsener, M.; Kleemann, M. Catal. Today 2000, 59, 335 doi: 10.1016/S0920-5861(00)00299-6

(4) Madia, G.; Koebel, M.; Elsener, M.; Wokaun, A. Ind. Eng. Chem. Res. 2002, 41, 3512. doi: 10.1021/ie0200555

(5) Andersson, J.; Antonsson, M.; Eurenius, L.; Olsson, E. Appl. Catal. B 2007, 72, 71. doi: 10.1016/j.apcatb.2006.10.011

(6) Winkler, A.; Ferri, D.; Aguirre, M. Appl. Catal. B 2009, 93, 177. doi: 10.1016/j.apcatb.2009.09.027

(7) Liang, Y.; Ding, X.; Zhao, M.; Wang, J.; Chen, Y. Appl. Surf. Sci. 2018, 443, 336. doi: 10.1016/j.apsusc.2018.03.032

(8) Després, J.; Elsener, M.; Koebel, M.; Kröcher, O.; Schnyder, B.; Wokaun, A. Appl. Catal. B 2004, 50, 73. doi: 10.1016/j.apcatb.2003.12.020

(9) Wang, H. F.; Guo, Y. L.; Lu, G.; Hu, P. J. Phys. Chem. C 2009, 113, 18746. doi: 10.1021/jp904371f

(10) Teranishi, T.; Hosoe, M.; Tanaka, T.; Miyake, M. J. Phys. Chem. B 1999, 103, 3818. doi: 10.1021/jp983478m

(11) Wang, X.; Sonström, P.; Arndt, D.; Stöver, J.; Zielasek, V.; Borchert, H.; Thiel, K.; Al-Shamery, K.; Bäumer, M. J. Catal. 2011, 278, 143. doi: $10.1016 /$ j.jcat.2010.11.020

(12) Xiong, Y.; Washio, I.; Chen, J.; Cai, H.; Li, Z. Y.; Xia, Y. Langmuir 2006, 22, 8563. doi: 10.1021/1a061323x

(13) Moon, S. Y.; Naik, B.; Jung, C. H.; Qadir, K.; Park, J. Y. Catal. Today 2016, 265, 245. doi: 10.1016/j.cattod.2015.08.036

(14) Rioux, R. M.; Song, H.; Hoefelmeyer, J. D.; Yang, P.; Somorjai, G. A. J. Phys. Chem. B 2005, 109, 2192. doi: 10.1021/jp048867x

(15) Song, H.; Kim, F.; Connor, S.; Somorjai, G. A.; Yang, P. J. Phys. Chem. B 2005, 109, 188. doi: 10.1021/jp0464775

(16) Yuan, W.; Ren, J.; Kai, D.; Gui, L.; Tang, Y. Chem. Mater. 2000, 12, 1622. doi: $10.1021 / \mathrm{cm} 0000853$

(17) Zhao, S.; Liang, H.; Zhou, Y. Catal. Commun. 2007, 8, 1305. doi: 10.1016/j.catcom.2006.11.033

(18) Du, Y. K.; Yang, P.; Mou, Z. G.; Hua, N. P.; Jiang, L. Appl. Polym. Sci. 2006, 99, 23. doi: 10.1002/app.21886

(19) Zawadzki, M.; Okal, J. Mater. Res. Bull. 2008, 43, 3111. doi: 10.1016/j.materresbull.2007.11.006

(20) Krier, J. M.; Michalak, W. D.; Cai, X.; Carl, L.; Komvopoulos, K.; Somorjai, G. A. Nano Lett. 2015, 15, 39. doi: 10.1021/n1502566b

(21) Susut, C.; Chen, D. J.; Sun, S. G.; Tong, Y. Phys. Chem. Chem. Phys. 2011, 13, 7467. doi: 10.1039/C1CP20164F

(22) Koo, I. G.; Lee, M. S.; Shim, J. H.; Ahn, J. H.; Lee, W. M. J. Mater. Chem. 2005, 15, 4125. doi: 10.1039/B508420B

(23) Tu, W.; Liu, H. J. Mater. Chem. 2000, 10, 2207. 
doi: 10.1039/B002232M

(24) Tian, Z. Q.; Jiang, S. P.; Liu, Z.; Li, L. Electrochem. Commun. 2007, 9, 1613. doi: 10.1016/j.elecom.2007.03.006

(25) Lemus, J.; Bedia, J.; Calvo, L.; Simakova, I. L.; Murzin, D. Y.; Etzold, B. J. M.; Rodriguez, J. J.; Gilarranz, M. A. Catal. Sci. Technol. 2016, 6, 5196. doi: 10.1039/C6CY00403B

(26) Koczkur, K. M.; Mourdikoudis, S.; Polavarapu, L.; Skrabalak, S. E. Dalton Trans. 2015, 44, 17883. doi: 10.1039/C5DT02964C

(27) Luo, M.; Hong, Y.; Yao, W.; Huang, C.; Xu, Q.; Wu, Q. J. Mater. Chem. A 2015, 3, 2770. doi: 10.1039/C4TA05250A

(28) Ruiz-García, C.; Heras, F.; Calvo, L.; Alonso-Morales, N.; Rodriguez, J. J.; Gilarranz, M. A. Appl. Catal. B 2018, 238, 609. doi: 10.1016/j.apcatb.2018.07.054

(29) Ma, J.; Sun, H.; Su, F.; Chen, Y.; Tang, Y.; Lu, T.; Zheng, J. Int. J. Hydrog. Energy 2011, 36, 7265. doi: 10.1016/j.ijhydene.2011.02.142

(30) Wang, Y.; Ren, J.; Deng, K.; Gui, L.; Tang, Y. Chem. Mater. 2000, 12, 1622. doi: $10.1021 / \mathrm{cm} 0000853$

(31) Peng, R.; Li, S.; Sun, X.; Ren, Q.; Chen, L.; Fu, M.; Wu, J.; Ye, D. Appl. Catal. B 2018, 220, 462. doi: 10.1016/j.apcatb.2017.07.048

(32) Olsson, L.; Persson, H.; Fridell, E.; Skoglundh, M.; Andersson, B. J. Phys. Chem. B 2001, 105, 6895. doi: 10.1021/jp010324p

(33) Hauff, K.; Tuttlies, U.; Eigenberger, G.; Nieken, U. Appl. Catal. B 2012, 123-124, 107. doi: 10.1016/j.apcatb.2012.04.008

(34) Yu, Q.; Richter, M.; Kong, F.; Li, L.; Wu, G.; Guan, N. Catal. Today 2010, 158, 452. doi: 10.1016/j.cattod.2010.06.031

(35) Hatanaka, M.; Takahashi, N.; Takahashi, N.; Tanabe, T.; Nagai, Y.; Suda, A.; Shinjoh, H. J. Catal. 2009, 266, 182. doi: $10.1016 /$ j.jcat.2009.06.005

(36) Belopukhov, E. A.; Paukshtis, E. A.; Shkurenok, V. A.; Smolikov, M.
D.; Belyi, A. S. Procedia Eng. 2015, 113, 19.

doi: 10.1016/j.proeng.2015.07.281

(37) Wu, Y.; Wang, D.; Li, Y. Chem. Soc. Rev. 2014, 43, 2112. doi: 10.1039/C3CS60221D

(38) Erdemir, D.; Lee, A. Y.; Myerson, A. S. Acc. Chem. Res. 2009, 42, 621. doi: $10.1021 / \operatorname{ar} 800217 \mathrm{x}$

(39) Susut, C.; Nguyen, T. D.; Chapman, G. B.; Tong, Y. Electrochim. Acta 2008, 53, 6135. doi: 10.1016/j.electacta.2007.12.016

(40) Borodko, Y.; Humphrey, S. M.; Tilley, T. D.; Frei, H.; Somorjai, G. A. J. Phys. Chem. C 2007, 111, 6288. doi: 10.1021/jp068742n

(41) Hansen, T. W.; Delariva, A. T.; Challa, S. R.; Datye, A. K. Acc. Chem. Res. 2013, 46, 1720. doi: 10.1021/ar3002427

(42) Yang, Z.; Li, J.; Zhang, H.; Yang, Y.; Gong, M.; Chen, Y. Catal. Sci. Technol. 2015, 5, 2358. doi: 10.1039/C4CY01384K

(43) Liang, Y.; Ou, C.; Hao, Z.; Ding, X.; Ming, Z.; Wang, J.; Chen, Y. Ind. Eng. Chem. Res. 2018, 57, 3887. doi: 10.1021/acs.iecr.7b05316

(44) Ji, Y.; Bai, S.; Crocker, M. Appl. Catal. B 2015, 170-171, 283. doi: 10.1016/j.apcatb.2015.01.025

(45) Fridell, E.; Persson, H.; Westerberg, B.; Olsson, L.; Skoglundh, M. Catal. Lett. 2000, 66, 71. doi: 10.1023/A:1019074901578

(46) Ji, Y.; Toops, T. J.; Graham, U. M.; Jacobs, G.; Crocker, M. Catal. Lett. 2006, 110, 29. doi: 10.1007/s10562-006-0100-4

(47) Castoldi, L.; Lietti, L.; Forzatti, P.; Morandi, S.; Ghiotti, G.; Vindigni, F. J. Catal. 2010, 276, 335. doi: 10.1016/j.jcat.2010.09.026

(48) Li, L.; Shen, Q.; Cheng, J.; Hao, Z. Catal. Today 2010, 158, 361. doi: 10.1016/j.cattod.2010.04.038

(49) Zhang, T.; Li, H.; Yang, Z.; Cao, F.; Li, L.; Chen, H.; Liu, H.; Xiong, K.; Wu, J.; Hong, Z.; et al. Appl. Catal. B 2019, 247, 133. doi: 10.1016/j.apcatb.2019.02.005 